\title{
Culture of Diet and Utilization of Health Services on Stunting Cases in Children Aged 2-5 Years in Bangkalan East Java
}

\author{
Novita Eka Kusuma Wardani ${ }^{1, *}$ Ani Media Harumi ${ }^{2}$ Asih Media Yuniarti ${ }^{3}$ \\ 1,2Department of Midwifery, Poltekkes Kemenkes Surabaya, Indonesia \\ ${ }^{3}$ Department Of Public Health, Stikes Majapahit, Indonesia \\ *Corresponding author. Email: novita.wardani2020@gmail.com
}

\begin{abstract}
Stunting is the most common problem in developing countries, including Indonesia. The problem of stunting is a new issue that harms nutritional problems in Indonesia because it affects the physical and functional aspects of the child's body and increases the child's morbidity, even the stunting incident has become the focus of WHO to be resolved immediately. The incidence of stunting is 53.2\%. (East Java Provincial Health Office, 2015). Method: This study used a cross-sectional analytic design. With a sample of 109 respondents. The research site is at the Bangkalan Regional Health Center. The Variable Culture of Diet and Utilization of Health Services has a p-value (Sig) $<0.05$, meaning that each variable has a significant partial effect on the incidence of stunting in the model. Dietary culture has a value of sig $=0.000$, meaning that eating culture has a partial influence on the incidence of stunting. The utilization of health services has a sig $=0.003$, meaning that the respondent's behavior in utilizing health services has a partial influence on the incidence of stunting. The culture of the right diet and the utilization of available health services can reduce the incidence of stunting.
\end{abstract}

Keywords: stunting, diet culture, health services

\section{INTRODUCTION}

The problem of stunting is an issue that harms nutritional problems in Indonesia because it affects the physical and functional nature of the child's body and increases child morbidity, even the incidence of stunting has become the focus of the World Health Organization to be resolved immediately. The growth process experienced by toddlers is a cumulative result since the toddler was born. The state of good and healthy nutrition in the toddler years is an important foundation for his health in the future. Conditions that have the potential to interfere with the fulfillment of nutrients, especially energy and protein in children, will cause growth problems [1].

Basic Health Research data in 2013 shows that the national prevalence of stunting among children under five in Indonesia is $37.2 \%$, consisting of $18.0 \%$ very short and $19.2 \%$ short. This shows an increase in the prevalence of stunting compared to 2010 , namely $35.6 \%$ consisting of $18.5 \%$ very short and $17.1 \%$ short, and in $200736.8 \%$ consisting of $18.8 \%$ very short. and $18.0 \%$ short. Indonesia consists of 34 provinces and 20 of them have a stunting prevalence above the national average prevalence. According to WHO standards, an area is considered chronic if the prevalence of stunting reaches $20 \%$. The prevalence of toddler stunting in Bangkalan is still high when compared to the prevalence of East Java. Monitoring data on the nutritional status of East Java Province in 2015 shows that the prevalence of stunting under five in Bangkalan is the highest in East Java, which is $53.2 \%$, with details of the prevalence of very short under five is $27.4 \%$ and stunting is $25.8 \%$ [2].

Many factors affect the nutritional status of children, both direct and indirect factors. Culture is one of the indirect factors that affect the nutritional status of children. Diet culture is one of the factors that influence the mother's attitude in undergoing pregnancy, childbirth, and in the care of toddlers. The culture that is owned by Indonesia is very rich and diverse. Madura is one of the tribes that is rich in culture. The results of preliminary studies and data from the Ministry of Health show that there are several cultures in the Madurese ethnic that are related to maternal and child health. This culture includes the socio-nutritional culture of mothers during pregnancy and childbirth, during breastfeeding, 
and under five years of age. Besides, factors of food diversity and availability of access to health services are also indirect factors in the incidence of stunting.

Toddlers who are stunted increase the risk of decreased intellectual ability, inhibit motor skills, productivity, and increase the risk of degenerative diseases in the future. This is because stunted children tend to be more susceptible to obesity. After all, people with short bodies, ideally, are also low in weight. Gaining just a few pounds can cause a person's Body Mass Index (BMI) to rise above normal limits [2].

Based on this background, the researchers are interested in examining the analysis of the influence of cultural factors on diet and utilization of health services on stunting of children aged 2-5 years at the health center.

\section{MATERIAL AND METHOD}

The design used in this research is quantitative with an analytic observational design. The approach used is cross-sectional. The population in this study were all children aged 2-5 years in Socah, Kwanyar, and Bangkalan City Health Centers with a total of 153 children under five. The sample size in this study was 109 respondents, where the sample was taken by cluster random sampling based on the number of children under five with stunting at the Bangkalan District Health Center. The analysis used to determine the relationship between the independent variable and the dependent variable was carried out by statistical tests using the Logistic Regression test.

\section{RESULT}

Based on the results of the study, it was found that most children did not have the opportunity to eat a variety of foods $(44 \%)$. Most children are also free to eat what they want, nutritious or not $(72 \%)$. Children are not able to choose what type of food is nutritious or not, they will choose the type of food that is attractive in color and tastes good. It is the role of parents to choose nutritious food for their children by not letting them choose their own food. The number of children who did not receive exclusive breastfeeding was $39.4 \%$. this is one of the causes of many stunting cases in this region.

Table 1. Distribution of cultural dietary

\begin{tabular}{|l|c|c|}
\hline \multicolumn{1}{|c|}{ Diet Culture } & $\mathbf{n}$ & $\%$ \\
\hline Feeding Frequency Monitoring \\
\hline Never & 0 & 0 \\
\hline Rare & 9 & 8,2 \\
\hline Most time & 10 & 9,1 \\
\hline almost time & 20 & 18,3 \\
\hline Always & 70 & 64,2 \\
\hline Food Diversity Monitoring \\
\hline None & 49 & 44 \\
\hline
\end{tabular}

\begin{tabular}{|l|c|c|}
\hline \multicolumn{1}{|c|}{ Diet Culture } & $\mathbf{n}$ & \% \\
\hline Diverse & 40 & 36,7 \\
\hline Very diverse & 10 & 9,3 \\
\hline Food Prohibition \\
\hline None & 79 & 72,4 \\
\hline Yes & 30 & 27,5 \\
\hline Fast food \\
\hline Instant noodle & 10 & 9,1 \\
\hline Chips & 30 & 27,8 \\
\hline Others & 59 & 54,1 \\
\hline Exclusive breastfeeding \\
\hline No & 43 & 39,4 \\
\hline Yes & 66 & 60,6 \\
\hline Total & $\mathbf{1 0 9}$ & $\mathbf{1 0 0}$ \\
\hline
\end{tabular}

Table 2. Distribution of health service utilization $(\mathrm{n}=109)$

\begin{tabular}{|l|c|c|}
\hline \multicolumn{1}{|c|}{$\begin{array}{c}\text { Utilization of Health } \\
\text { Services }\end{array}$} & $\mathbf{n}$ & \% \\
\hline Availability of Posyandu & & \\
Available & 60 & 55 \\
Non Available & 49 & 45 \\
\hline Utilization of Posyandu & 74 & 67,8 \\
Utilize & 35 & 32,2 \\
Non Utilize & \\
\hline
\end{tabular}

Based on table 2, children aged 2-5 years use health services by utilizing posyandu services (67.8\%). However, most of the respondents said that in their area there is no posyandu service.

Table 3. Distribution of stunting incident $(n=109)$

\begin{tabular}{|l|l|l|}
\hline \multicolumn{1}{|c|}{ Stunting Incident } & $\mathbf{n}$ & \% \\
\hline Stunting & 40 & 36,7 \\
\hline Normal & 69 & 63,3 \\
\hline
\end{tabular}

Based on table 3, almost half of the children aged 25 years experienced stunting $(36.7 \%)$. This figure should not be underestimated because stunting is an event that should not happen.

The Variables in the equation table 4 shows that all independent variables have a $\mathrm{P}$ value $(\mathrm{Sig})<0.05$, meaning that each variable has a significant partial effect on $\mathrm{Y}$ in the model.

$\mathrm{X} 1$ or dietary culture (inappropriate) $\mathrm{sig}=0.000$, meaning inappropriate dietary culture has a partial effect on the incidence of stunting. Meanwhile, X2 or the utilization of health services (which do not utilize) $=$ 0.003 , meaning that the behavior of respondents who do not utilize health services has a partial effect on the incidence of stunting. constant $=0.000$ so that the equation for the regression model is:

$\operatorname{Ln}(p / p-1)=-3.944-4.424 X 1+3.341 \times 2$

Table 4. Partial test of Logistic Regression

\begin{tabular}{|c|c|c|c|c|}
\hline & B & Sig. & $\operatorname{Exp}(B)$ \\
\hline \multirow{3}{*}{$\begin{array}{l}\text { Step } \\
1^{\text {a }}\end{array}$} & dietary_culture(1) & 4.424 & .000 & 83.443 \\
\hline & Utilization_health_serv(1) & 3.341 & .003 & 28.235 \\
\hline & Constant & -3.944 & .000 & .019 \\
\hline
\end{tabular}




\section{DISCUSSION}

Food for children is needed in the process of growth and development (golden age periods). This study proves that the culture of eating patterns has a partial effect on the incidence of stunting value $<0.05$. The picture of the culture of eating patterns in this study shows that most parents do not have food abstinence in providing food for their toddlers. However, parents also give fast food in their toddler's diet $(54.1 \%)$. The data in this study also shows that most parents do not monitor the diversity of food on their toddler's diet (44\%). The characteristics of the respondents in this study were mostly women. According to Biwas (2010), birth order discrimination in boys and girls can affect the fulfillment of nutrition in toddlerhood. Arifin (2015), explains that the nutritional needs of adults are different from the nutritional needs of toddlers because during infancy there is very rapid growth and development, with increasing age, a person's nutritional needs are relatively lower for each kilogram of body weight. . Inappropriate dietary culture obtained in this study can affect the incidence of stunting in children under five. This is in line with the research of Sebayang, which explains that the incidence of stunting is influenced by the inadequate proportion of minimum dietary diversity (MMD) [3].

A similar study was also put forward by Roesler, et al (2018) which explained that stunting mostly occurs at the age of under 5 years and the presence of stunting reflects the diversity of poor diets, especially at the age of 6-11 months. According to Utami (2017), food consumption is a vital component that has an important role in determining the nutritional status of children. One of the indicators of the quality of children's consumption is determined based on the diversity of food [4]

The characteristics of the last education of the respondents' parents in this study were mostly high school education. This is in line with the research of Shinta, et al. which explains that parental knowledge is needed in fulfilling optimal nutrition for toddlers. In this study, parents gave fast food to their toddler's diet [5]. The practice of giving fast food reflects the lack of understanding of parents in giving healthy food to their children. Based on the results of the research and theory above, it can be concluded that the understanding of parents in fulfilling the diversity of food in toddlers is needed in fulfilling the quality of food in their toddlers. Giving fast food to a minimum is avoided in a toddler's eating pattern culture which is still in the golden period [1].

The ability of a family in the ability of a household to access health services is related to the availability of health service facilities and the economic ability to pay the cost of services. In this study, most of the respondents' domicile areas have health service facilities. Most of the respondents' parents $(67.8 \%)$ used the health services around their homes. In this study, the health services used by the respondent's parents were Health center and posyandu [3].

The income of the respondents' parents in this study ranged from 500,000 to 2,000,000 rupiah's (88.07\%). According to Widyantari (2018), income is also related to the fulfillment of food quality. Low income causes low purchasing power as well, so they are unable to buy food in the required amount. This situation is very dangerous for the health of the family and ultimately can have a bad impact on the nutritional status, especially for infants and toddlers. According to Ratu (2010), health is very sensitive to changes in the economic situation. Disruption of the economic situation will interfere with the accessibility of the community and family to health services, for example, immunization services, care related to growth, morbidity, and mortality of children. Access to health services is seen from the distance and travel time as well as the costs incurred to achieve health services. The existence of community-based financing facilities and stunting can improve the nutritional status of children under five [3].

Posyandu is a facility that utilizes community resources and is managed by the community. The use of posyandu in the community is influenced by several factors, including people coming to the posyandu because the facilities and infrastructure are available, the quality of service is considered good, there is a role from community leaders, and the community is unable to take children to other service facilities.

The use of Posyandu in overcoming stunting problems is by the vision of the ministry of health, namely creating a healthy and independent society with a mission to improve public health status, through community empowerment, including the private sector and civil society. Posyandu is a form of Community Based Health Efforts carried out by, from, and with the community, to empower and provide convenience to the community to obtain health services for mothers, infants, and toddlers. The target community of the posyandu is following the target of specific nutrition interventions for stunting management. Posyandu is a place for pregnant women, breastfeeding, infants, and toddlers to get services in the form of monitoring growth and development, giving vitamin A capsules, immunization, prevention and control of diarrhea, nutritional counseling according to the problem and family planning [6].

\section{CONCLUSION}

Culture of diet and utilization of health services had relationship with stunting. The culture of the right diet and the utilization of available health services can reduce the incidence of stunting. the availability of health services in the form of health center, Posyandu, midwives can help the community in obtaining maternal and child health services, to prevent stunting from 
occurring during pregnancy. The utilization of health services by the community needs to be maintained so that stunting can be prevented early.

\section{AUTHORS' CONTRIBUTIONS}

NEKW: concept and design, writing, data collection, data analysis, AMH: writing, data collection, data analysis, review, AMY: writing, data collection.

\section{ACKNOWLEDGMENTS}

The authors would express the gratitude and acknowledgements to all study participants and study team members for their time and energy spent on this project.

\section{REFERENCES}

[1] Mediani, H. S. Predictors of Stunting Among Children Under Five Year of Age in Indonesia: A Scoping Review. Glob. J. Health Sci. 12, 83 (2020).

[2] Titaley, C. R., Ariawan, I., Hapsari, D. \& Muasyaroh, A. Determinants of the Stunting of Children in Indonesia: A Multilevel Analysis of the 2013 Indonesia Basic Health Survey. Nutrients 11, 1160 (2013).

[3] Sebayang, S. K. et al. Determinants of ageappropriate breastfeeding, dietary diversity, and consumption of animal source foods among Indonesian children. Matern. Child Nutr. 16, 1-19 (2020).

[4] Roesler, A. L., Smithers, L. G., Wangpakapattanawong, P. \& Moore, V. Stunting, dietary diversity and household food insecurity among children under 5 years in ethnic communities of northern Thailand. J. Public Heal. (United Kingdom) 41, 772-780 (2019).

[5] Shinta, H. E., Utami, P. J. \& Adiwijaya, S. Potential Stunting in Riverside Peoples (Study on Pahandut Urban Village, Palangka Raya City). Budapest Int. Res. Critics Inst. Humanit. Soc. Sci. 3, 1618-1625 (2020).

[6] Hall, C. et al. Maternal Knowledge of Stunting in Rural Indonesia. Int. J. Child Heal. Nutr. 7, 139145 (2018). 